\title{
Sequence determination of 16s ribosomal RNA for ruminal ammoniabacters of Holstein cows
}

Mohammad Reza Nassiry, Mohsen Danesh Mesgaran, Ali Reza Vakili, Ali Javadmanesh

Excellence Center for Animal Science, Ferdowsi University of Mashad, Mashad, Iran

Email:m_nassiry@yahoo.com

Introduction Protein degradation in the rumen often proceeds at a rate which exceeds the ability of the microbial population to utilize the resulting breakdown products. Bacteria are the most active proteolytic organisms in the rumen, and many species of rumen bacteria are known to be proteolytic (Wallace et al., 1985). The commonly isolated proteolytic bacteria are also able to break down peptides and amino acids, and it was assumed that they were responsible for the ruminal degradation of intact protein through to ammonia. However, studies comparing the specific activities of ammonia production between mixed ruminal bacteria and the well-known proteolytic bacteria noted that no individual bacterium had an activity which could explain the activity of the mixed ruminal culture (Russell et al., 1988). Subsequently, three grampositive, monensin-sensitive, ammonia hyper producing (HAP) bacteria were isolated from the rumen. The present study reports the sequence of $16 \mathrm{sr}$ RNA for ruminal ammoniabacters of Iranian Holstein cows.

Materials and methods Rumen samples were collected from 10 fistulated mid lactation Holstein cows (30 \pm 3.6 milk production) fed $19 \mathrm{~kg}$ dry matter of a diet (58:42 forage:concentrate) containing 18\% CP and 1.56 Mcal/kg DM NEL. Rumen fluid was centrifuged for $10 \mathrm{~min}$ in 3000rpm then DNA was extracted from $200 \mu \mathrm{l}$ of supernatant by Guanidinium Thiocyanate-Silica Gel method (Boom et al., 1990).

In a volume of $20 \mu \mathrm{l}$ which consisted of $50 \mathrm{ng}$ of template DNA, PCR reaction contained: $2.5 \mu \mathrm{l}$ PCR buffer 10-X (200 mM $\left(\mathrm{NH}_{4}\right)_{2} \mathrm{SO}_{4}, 0.1 \mathrm{mM}$ Tween $20,750 \mathrm{mM}$ Tris-HCl, and $\left.\mathrm{pH}=8.8\right), 2.5 \mathrm{mM} \mathrm{MgCl}, 200 \mu \mathrm{M}$ dNTs, and $10 \mathrm{pM}$ of oligonucleotids, $1 \mathrm{U} \mathrm{Taq}$ DNA polymerase. Thermal condition consisted with thirty-five cycles of $95^{\circ} \mathrm{C}(1 \mathrm{~min}), 62^{\circ} \mathrm{C}(1$ $\mathrm{min})$, and $72^{\circ} \mathrm{C}(2 \mathrm{~min})$ followed by $72^{\circ} \mathrm{C}(8 \mathrm{~min}) .16$ sRNA gene was amplified to a product of $1500 \mathrm{bp}$ fragment using the primers described by Attwood et al. (1998). Primer sequences were FD1: 5'-GAGTTTGATCCTGGCTCAG-3' and RD1: 5'-AAGGAGGTGATCCAGCC-3'.

PCR products were visualized by electrophoresis on $1 \%$ agarose gel stained with etithium bromide. PCR product after purification was sequenced for analysis of $16 \mathrm{~s}$ ribosomal RNA. The obtained sequence was analyzed with Chromas Lite 2.01 software and aligned with BLAST 2.0 for finding similarity with other sequences.

Results Extracted DNA had a good quality and 1500 bp fragments of 16s rRNA from ammoniabacters and fibrobacters was amplified successfully (Figure 1). Sequence of purified PCR product showed a high homology with other sequences with accession number of DQ394612, DQ394611 and DQ394610.

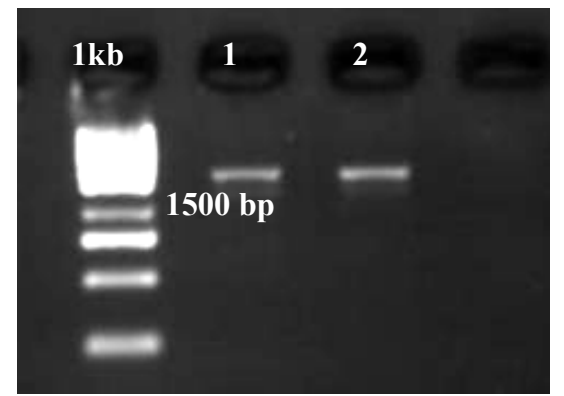

Figure 1 Agarose (1\%) electrophoresis of $1500 \mathrm{bp}$ fragment of $16 \mathrm{~s}$ rRNA (Lanes 1 and 2). DNA Ladder is $1 \mathrm{Kbp}$ (Fermentas).

Conclusions This is the first study to report the sequence of 16 s ribosomal RNA for ruminal ammoniabacters. Phylogenetic study of ruminant bacteria is very important for detection and modification of rumen flora. Such a sequencing method is suitable for detecting bacteria. For exact determination in experimental an industrial purposes, we recommend specific culture for special bacteria.

Acknowledgements This investigation was supported by Excellence Centre for Animal Science, Agriculture Faculty, Ferdowsi University of Mashhad.

\section{References}

Attwood, G. T., A. V. Klieve, D. Ouwerkerk and B. K. C. Patel. 1998. Ammonia-Hyperproducing bacteria from new zealand ruminants. Applied and environmental microbiology. 64 (5): 1796-1804.

Russell, J. B., H. J. Strobel, and G. Chen. 1988. Enrichment and isolation of aruminalbacterium with a very high specificactivity of ammonia production. Applied and environmental microbiology. 54: 872-877.

Wallace, R. J., and M. L. Brammall. 1985. The role of different species of bacteria in the hydrolysis of protein in the rumen. J. Gen. Microbiol. 131: 821-832.

Boom R., Sol C.J., Salimans M.M. 1990. Rapid and simple method for purification of nucleic acids. Clinical Microbiology. 28 (3): 495-503. 